\title{
Macroscopic and Microscopic Modifications of Wood after Debarking of Trees in the South Cameroon
}

\author{
Ghislain Kenguem Kinjouo ${ }^{1}$, Marie Caroline Momo Solefack ${ }^{1} \&$ Victor François Nguetsop $^{1}$ \\ ${ }^{1}$ Department of Plant Biology, Faculty of Science, University of Dschang, P.O. Box 67, Dschang, Cameroon \\ Correspondence: Marie Caroline Momo Solefack, Department of Plant Biology, Faculty of Science, University \\ of Dschang, P.O. Box 67, Dschang, Cameroon. E-mail: mcarofr@yahoo.fr
}

Received: January 23, 2021

Accepted: March 4, $2021 \quad$ Online Published: March 20, 2021

doi:10.5539/jps.v10n1p30

URL: https://doi.org/10.5539/jps.v10n1p30

\begin{abstract}
Wounding of trees by debarking has been reported to form a callus tissue. This work aims to investigate macroscopic and microscopic modifications of wood after the removal of barks in Alstonia boonei, Scorodophloeus zenkeri, and Garcinia lucida. Species that are not yet barking were wounded to conducting experimental debarking. The wound was rectangular with $30 \mathrm{~cm}$ vertically with a lateral extent of $10 \mathrm{~cm}$. Every three months, there was a follow-up for fifteen months during which the macroscopic and microscopic phenomena were observed and recorded. Microsections of 15-20 $\mu \mathrm{m}$ thickness were taken on a piece of wood from the regenerated and intact wood, with a sledge microtome. Staining of cell walls was done with safranin and fast green to increase contrast in an anatomical slide. Analyzes of the variability of xylem anatomical features were done by semi-automatic measurements using the SpectrumSee digital image analysis software. The speed of recovery of the bark of these three species is $9.04 \mathrm{~cm} /$ year for $A$. boonei, $5.9 \mathrm{~cm} /$ year for $S$. zenkeri, and $3.85 \mathrm{~cm} /$ year for G. lucida. The recovery of A. boonei's bark is the fastest, and it just takes 15 months to heal its wound. Densities of vessels were 8,38 , and 17 per $\mathrm{mm}^{2}$, respectively, for the wood of A. boonei, S. zenkeri, and G. lucida before barking. These values increased for A. boonei (26) and G. lucida (20) except for $S$. zenkeri (25). In all species, the diameter of the vessels has decreased in the regenerated wood. Management practices that enhance the monitoring of sustainable harvesting levels of species and promote alternative plants for the same uses should be considered as part of conservation strategies.
\end{abstract}

Keywords: Alstonia boonei, anatomy, Garcinia lucida, recovery, Scorodophloeus zenkeri

\section{Introduction}

Forests provide many ecosystem services that are not currently valued in economic terms, and their loss can have significant negative impacts on health and livelihoods, especially among the rural poor for whom forests are often important safety net (Wunder, 2001). Approximately $40 \%$ of the rural populations live in situations of extreme poverty and these 250 million people live in the forestry zones of or savanna (FAO, 2018). These counteracting forces make it difficult to generalize about the impacts of deforestation and forest degradation on people living in forest landscapes (Turner et al., 2012).The Cameroonian forest, covers an area of about 22,523,732 hectares, which represents about $48 \%$ of the national territory (de Wasseige et al., 2009). The importance of the forest is related to its multiple and sometimes conflicting uses and functions at local, national and global levels. From a conservation perspective, the forest constitutes a crucial reservoir of biodiversity, including many endemic species, and its contribution to climate regulation and other environmental services.

In Africa, Non-Timber Forest Products (NTFPs) represent direct inputs to satisfy different household needs for food, medicine, and materials for construction. In Cameroon, NTFPs constitute a regular source of income (even though not the most important) for rural households due to their diversity (Awono et al., 2016). Non-timber forest products (NTFP) from tropical forests have become a subject of mounting international concern as a result of several factors which affect the availability of many tropical species. In fact, continuing deforestation in the tropics threatens to eliminate hundreds, if not thousands, of species during the next few decades (Hall \& Bawa, 1993).With a growing appreciation of the importance of NTFPs and their potential role in the socio-economic well-being of especially rural communities (Ticktin et al., 2006), the harvesting of NTFPs is now recognised as an important aspect of the sustainable management of natural forests (Mahapatra \& Mitchell, 1997).

NTFP harvest can affect ecological processes at many levels, from individual and population to community and 
ecosystem. However, the majority of research was focused at a population level and on a limited subset of plant parts that are harvested. Tolerance to harvest varies according to life history and the part of plant that is harvested. Moreover, the effects of harvest for any one species are mediated by variation in environmental conditions over space and time, and by human management practices (Ticktin, 2004). Different parts of plants are harvested for NTFPs. Although the uses of these products are very different, their harvest may produce impacts that can be either beneficial or detrimental to the species. The actual impact of harvesting depends on the specific growth form or type of resource that is removed. Intensive and uncontrolled harvesting can reduce the abundance of solitary plants (Stewart, 2003; Bitariho et al., 2006). The harvesting of roots, bulbs and bark usually kills or fatally weakens the exploited plant species (Davenport \& Ndangalasi, 2002).

The exploitation of tree species has a variable effect depending on the parts harvested since harvesting of the bark is more damaging in terms of tree survival (Geldenhuys et al., 2007; Vermeulen, 2009). The bark is that portion of the plant body consisting of all tissues external to the vascular cambium (Esau, 1967). It may thus be composed of phloem, cortex, periderm, and remnants (if any) of the epidermis. This complex tissue composition permits the bark to simultaneously perform manifold functions, among which sap conduction; photosynthesis, tissue aeration, and protection from the external environment are well known. The bark also protects plants against fire, fungal and insect attack (Cunningham, 2001). Removal of bark can therefore damage phloem or expose it to desiccation and fungal or parasite attack. This may disrupt the conduction of nutrients and hormones involved in flower bud production for example (Mohr \& Schopfer, 1995).

The forests of Ngovayang in southern Cameroon are shelter species producing non-timber forest products, including A. boonei which is a tropical plant reputed in traditional medicine to have anti-malarial, antipyretic, analgesic and anti-inflammatory properties (Bello et al., 2009). A. boonei is among the plants due to its ethno-medicinal uses and pharmacological activities, used for COVID-19 prevention, alleviate symptoms, treatment and baseline for anti-COVID-19 drug discovery (Tsobou et al., 2020). G. lucida seeds and bark are the parts mostly used for the treatment of various diseases such as the diarrhoea, abdominal pains, constipation, gastric evil, gynaecological infections, and sexually transmitted diseases (Guedje et al., 2017). The bark of $S$. zenkeri is consumed to relieve the problems of constipation. The bark can also be used with other plants to treat the cold, cough, and rheumatism (Eyog et al., 2006). Bark harvested from these species are commonly used traditional medicine but, due to increasing urbanisation, has become highly commercialised. Bark harvesting interrupts suddenly the water relationship between bark and wood and may affect the water conduction between leaves and roots (Zwieniecki et al., 2004). As trees consume large amounts of water, they have to develop mechanisms for protection against disturbance of their water balance whereas they should be able to restore the water pathway. Both the diameter and the density of vessels directly influence conductivity (Sellin et al., 2008).

The aim of this study was to evaluate the responses following the tree debarking. Since vessel features can be considered as indicators of anatomical wood reactions following bark harvesting, we should investigate the impact of the wood after fifteen months by evaluating the features of vessels and other wood elements produced before and after bark harvesting.

\section{Material and Methods}

\subsection{Location of Study Area}

The Ngovayang Massif Area (c. $527 \mathrm{~km}^{2}$ ) is located in Atlantic Central Africa (South Region of Cameroon), which mainly corresponds to the Lower Guinea subregion, the floristically richest phytochorion of the Guineo-Congolian region (Droissart et al., 2018). It is covered by lowland and submontane rainforest (100 to $1110 \mathrm{~m}$ elevation). The lowland forests of Ngovayang Massif Area are dominated by Fabaceae-Caesalpinioideae (Droissart et al., 2019). The Ngovayang Mountain, which constitutes a dense intrusive rock (Kuepetou et al., 2017), according to some prospecting activities, would potentially be rich in useful minerals. This region is also drained by a very dense hydrographic net-work whose waters would facilitate the transport of materials (Mioumnde et al., 2019).The climate is of the sub-equatorial type (Suchel, 1972). The climate is humid tropical with two distinct wet seasons (August - November, March - May) and two dry seasons in a year (May-August, November-March), associated with the movement of the intertropical convergence zone over the area. The average annual precipitation is around $2000 \mathrm{~mm}$ and the average annual temperature is $25{ }^{\circ} \mathrm{C}$ (Waterloo et al., 2000).

\subsection{Description of Study Species}

\subsubsection{Alstonia boonei}

Alstonia boonei is a very large, deciduous, tropical-forest tree belonging to the family Apocynaceae. It is a tall 
forest tree, which can reach 45 metres in height and $3 \mathrm{~m}$ in girth, the bole being cylindrical and up to $27 \mathrm{~m}$ in height with high, narrow, deep-fluted buttresses. The latex is white and abundant. The wood is fine-grained, lending itself to detailed carving (Burkhill, 1985). The heartwood is yellowish white, though darkening upon exposure to light; it is not distinctly demarcated from the sapwood. The grain is straight, occasionally wavy; the texture moderately coarse; lustre low; there is no distinctive odour or taste. The wood is soft, light in weight, interspersed with latex vessels and inclined to be gummy (Palla, 2005).

\subsubsection{Garcinia lucida}

G. lucida is a tree of the family of Clusiaceae or Guttiferae. This species can reach $25 \mathrm{~m}$ height and its diameter seldom reaches $30 \mathrm{~cm}$. The base of the trees of G. lucida generally has stilts roots which can simple or be ramified. This tree has a rectilinear and cylindrical trunk which is covered with a rough bark and with the bitter taste. This species has a yellow exudation which runs out slowly. The lower branches are laid out horizontally and staged, while the higher branches are laid out obliquely and drawn up (Eyog et al., 2006).

\subsubsection{Scorodophloeus zenkeri}

S. zenkeri (Fabaceae) is a tree up to $35 \mathrm{~m}$ tall and $200 \mathrm{~cm}$ in diameter. Its trunk is straight and more or less cylindrical. The base is slightly thickened and has grooves. The top of this tree is open with upright branches. The bark of $S$. zenkeri is gray-yellow, smooth in young individuals then scaly and may have a slice about $1 \mathrm{~cm}$ thick, brittle, yellow with a garlic odour (Eyog et al., 2006).

\subsection{Sampling Design and Treatment after Harvesting}

Experimental barking was carried out on 52 individuals of a class of diameter ranging between 10 to $100 \mathrm{~cm}$ (Table 1). Only the trees which were never been barked were selected for the experiment. The bark of each tree was collected to approximately $1.30 \mathrm{~m}$ height.

Table 1. Number of individuals observed as well as the diameter at breast height (DBH) for each species

\begin{tabular}{llll}
\hline Species & Family & N & DBH $(\mathrm{cm})$ \\
\hline Alstonia boonei & Apocynaceae & 20 & $17-109$ \\
Garcinia lucida & Clusiaceae & 16 & $10-17$ \\
Scorodophloeus zenkeri & Fabaceae & 16 & $10.5-50$ \\
\hline
\end{tabular}

On each individual, the wound consisted of a rectangular piece of bark $30 \mathrm{~cm}$ vertically, and the lateral extent of the wound was $10 \mathrm{~cm}$. After each three months, measures of covering of the bark were taken to determine the evolution of the growth of bark.

Cubes of about $1 \mathrm{~cm}^{3}$ were taken before and after debarking from the regenerated area from six individuals of each species. Samples were sectioned in transverse sections $(15-20 \mu \mathrm{m}$ thickness) with sliding microtome. The microscopic slides were progressively dehydrated in an ethanol series and double stained with Safranin O-Fast Green. This double staining is performed to differentiate the cell walls in terms of color under an optical microscope. After staining, the sections were dehydrated in solutions with increasing concentrations of ethanol, mounted between slides and lamellae in the eukitt and air-dried. The bark recovery rate was assessed by observation of the surface covered with cicatrization tissue after 3 months, as expressed in $\mathrm{cm}^{2} / y e a r$. In order to determine the anatomical variables that could help predicting the potential of tree species to show a good bark recovery rate, a total of five anatomical variables was measured in the xylem zone. The percentage surface area of each tissue was measured semi-automatically: vessels, fibres, rays and parenchyma. The description of the cicatrization tissue was carried out. These measurements were made using cuttings immediately in contact with the cambial zone (Momo et al., 2017).

\subsection{Statistical Analysis}

All of the semi-automatic measurements such as the density of the vessels in $\mathrm{mm}^{2}$, the surface of the vessels, the surface occupied by the vessels, the surface occupied by fibres, the surface occupied by the parenchyma and surfaces occupied by the rays were made using the SpectrumSee-F digital image analysis software. EXCEL 2007 (Microsoft office) made it possible to organize the data resulting from recovering of the various species. Statistical analyses were carried out using the SPSS software specifically the averages of bark recovery speed were separated by the variance analysis (ANOVA), and the areas occupied by various anatomical elements were separated by the $t$-Student test. 


\section{Results}

\subsection{Macroscopic Characteristics after Debarking}

The figure 1 shows the species at the time of debarking in January 2018, the dry season, and six months after debarking in June 2018 corresponding to dry season. We discover that wound closure began simultaneously from the margins of the wound (edge growth) and from the entire exposed surface of the wounded xylem (sheet growth). At the end of fifteen months of observations, no individual died or was attacked by the insects; therefore all the species resisted barking.

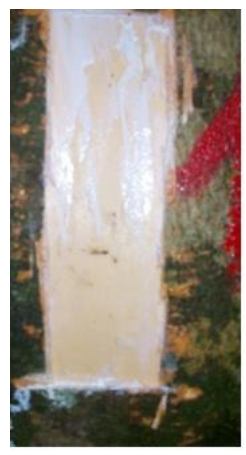

A

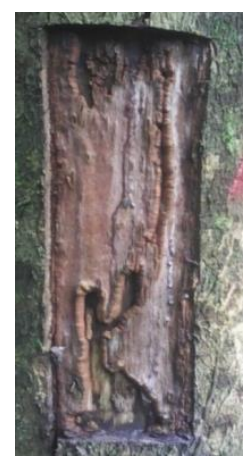

$\mathrm{B}$

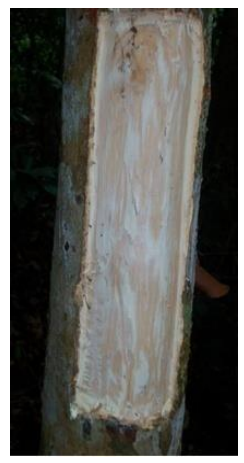

A

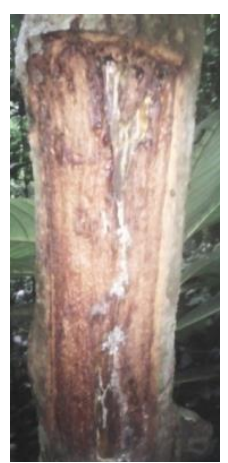

$\mathrm{B}$

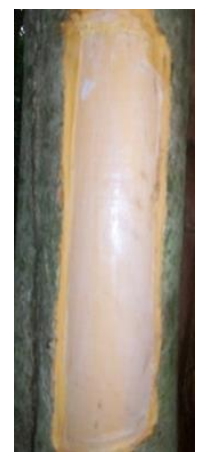

A

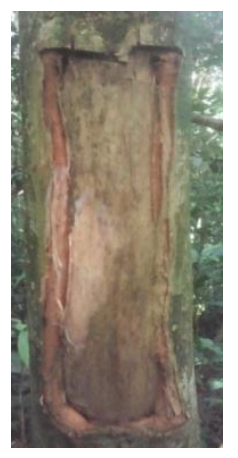

$\mathrm{B}$

Alstonia boonei

\section{Scorodophloeus zenkeri}

Figure 1. Illustration of recovery of the bark of A. boonei, G. lucida and S. zenkeri at the time of debarking (A) and six months after debarking (B)

The recovery rate of the bark of Alstonia boonei, Scorodophloeus zenkeri and Garcinia lucida 15 months after debarking is presented in Table 2 . In the three first months, recovery rate of Alstonia boonei was $3.21 \mathrm{~cm}$. Six months after debarking, the recovery rate has evolved and reached a maximum of $3.39 \mathrm{~cm}$ then decreased gradually. The lowest value of recovery was recorded 15 months after debarking $(0.75 \mathrm{~cm})$, since after this period, the wound was completely healed.

The bark recovering rate of $S$. zenkeri has evolved in the shape of the wave. In the three first months, the recovering rate was $1.41 \mathrm{~cm}$. Six months after debarking, the recovering rate has evolved and arrived to $1.68 \mathrm{~cm}$, then started decreasing the six next months. Fifteen months after wounding, the recovering rate has increased again to reach a maximum rate which is $2.24 \mathrm{~cm}$ (Table 2).

As concerning G. lucida, the recovering rate of bark of this species has evolved in the shape of wave. In the three first months, the recovering rate was $0.63 \mathrm{~cm}$. This recovering rate has evolved and reached $1.23 \mathrm{~cm}$ six months after debarking, then started decreasing till $0.87 \mathrm{~cm}$ after 12 months. Fifteen months after experimental wounding, the recovery rate has increased considerably to reach $1.67 \mathrm{~cm}$ (Table 2).

Table 2. Recovery rate of the bark of A. boonei, S. zenkeri and G. lucida after debarking

\begin{tabular}{llll}
\hline & \multicolumn{3}{l}{ Recovery rate $(\mathrm{cm})$} \\
\hline Time after debarking & A. boonei & S. zenkeri & G. lucida \\
\hline 3 months & $3.21 \pm 1.23$ & $1.41 \pm 0.80$ & $0,63 \pm 0.95$ \\
6months & $3.39 \pm 2.70$ & $1.68 \pm 2.13$ & $1,23 \pm 3.07$ \\
9months & $1.46 \pm 2.24$ & $1.48 \pm 2.19$ & $1.12 \pm 3.17$ \\
12months & $0.98 \pm 1.79$ & $1.34 \pm 2.62$ & $0.87 \pm 3.25$ \\
15months & $0.71 \pm 0.75$ & $2.24 \pm 2.27$ & $1.63 \pm 3.74$ \\
\hline
\end{tabular}

Note. 3 months: $18^{\text {th }}$ April; 6 months: $18^{\text {th }}$ June; 9 months: $18^{\text {th }}$ September; 12 months: $19^{\text {th }}$ December; 15 months: $19^{\text {th }}$ March

Table 3 shows the bark recovery speed of the three species per year. It was noticed that the bark recovery speed of the bark of $A$. boonei per year was significantly higher $(9.04 \mathrm{~cm}$ per year) compared to those of the species $S$. zenkeri $(5.91 \mathrm{~cm}$ per year) and G. lucida $(3.85 \mathrm{~cm}$ per year). Fifteen months after debarking, A. boonei completely healed its wound. 
Table 3. Bark recovery speed (cm per year) of Alstonia boonei, Scorodophloeus zenkeri, and Garcinia lucida

\begin{tabular}{ll}
\hline Species & Recovery rate (cm per year) \\
\hline Alstonia boonei & $9.04^{\mathrm{a}} \pm 1.79$ \\
Scorodophloeus zenkeri & $5.91^{\mathrm{b}} \pm 2.62$ \\
Garcinia lucida & $3.85^{\mathrm{b}} \pm 3.25$ \\
\hline
\end{tabular}

${ }^{\mathrm{a}, \mathrm{b}}$ : Averages with the same letters on the same column are not significant at the 5\% threshold.

\subsection{Variation of the Anatomical Features before Barking and during the Closing of the Wound}

The densities of the vessels before and after the barking of each species were summarizes in Figure 2. In the wood of Alstonia boonei, the density of the vessels was 8 vessels per $\mathrm{mm}^{2}$ before barking and 26 vessels in the regenerated wood.

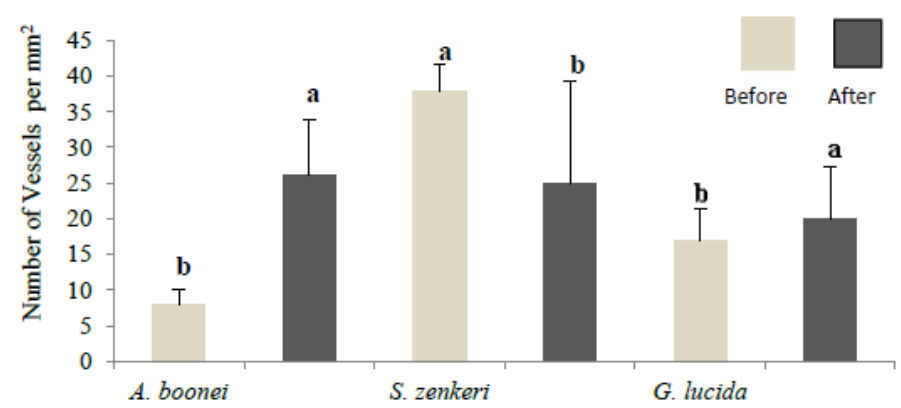

Figure 2. Density of the vessels in the wood before and after debarking

${ }^{\mathrm{a}, \mathrm{b}}$ : Histogram bars with the same letters are not significant at the $5 \%$ threshold

According to $t$ test (test of student), there was a significant difference between the density of the vessels taken before and after the wood recovery $(\mathrm{P} \leq 0.05)$. In the wood of $S$. zenkeri the density of the vessels after debarking was significantly lower ( 25 vessels per $\left.\mathrm{mm}^{2}\right)$ than that of before wounding $\left(38\right.$ vessels per $\left.\mathrm{mm}^{2}\right)(\mathrm{P} \leq 0.05)$. G. lucida wood has shown a significantly increasing number of vessels $\left(20 / \mathrm{mm}^{2}\right)$ in the regenerated wood $(\mathrm{P} \leq 0.05)$ as compare to wood before wounding.

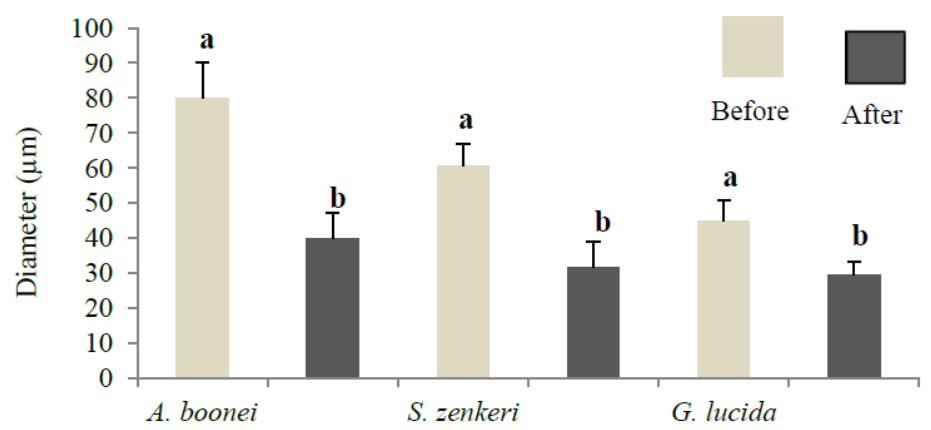

Figure 3. Diameter of the vessels in wood before and after debarking

${ }^{\mathrm{a}, \mathrm{b}}$ : Histogram bars with the same letters are not significant at the $5 \%$ threshold

The diameter of the vessels before wounding and in the regenerated wood is presented in figure 3. In all those species, the diameter of the vessels has decreased in there generated wood. In the wood of A. boonei, there was a significant difference between the diameter of vessels taken before $(80.18 \mu \mathrm{m})$ and after bark recovery $(39.78 \mu \mathrm{m})$ $(\mathrm{P} \leq 0.05)$. The same trend was observed in the $S$. zenkeri wood, where the diameter of the vessels decreases significantly $(\mathrm{P} \leq 0.05)$ from $60.55 \mu \mathrm{m}$ before debarking to $31.59 \mu \mathrm{m}$ in the regenerated wood. In the G. lucida wood, the diameter of the vessels was smaller compared to other species, but the same trend was observed, since it decreases significantly from $44.91 \mu \mathrm{m}$ to $26.42 \mu \mathrm{m}$ in the regenerated wood $(\mathrm{P} \leq 0.05)$.

Anatomical features of xylem in term of area in the sample collected before wounding and in the regenerated wood were presented in Table 4. 
Table 4. Areas occupied by various anatomical elements in the xylem before and after wounding

\begin{tabular}{llllll}
\hline Species & \multirow{2}{*}{ Barking } & \multicolumn{4}{l}{ Area occupied by anatomical elements measured in the xylem $\left(\mu \mathrm{m}^{2} \mathrm{x} 1000\right)$} \\
\cline { 3 - 6 } & & Vessels & Fibers & Rays & Parenchymas \\
\hline A. boonei & Before & $7.26 \pm 4.17$ & $53.82 \pm 2.31$ & $12.39 \pm 3.63$ & $12.80 \pm 7.04$ \\
& After & $2.08 \pm 5.68$ & $37.73 \pm 1.86$ & $21.71 \pm 9.57$ & $42.90 \pm 5.73$ \\
& & $\mathrm{P} \leq 0.05$ & $\mathrm{P} \leq 0.036$ & $\mathrm{P} \leq 0.008$ & $\mathrm{P} \leq 0.005$ \\
S. zenkeri & Before & $3.70 \pm 5.70$ & $53.85 \pm 15.46$ & $8.26 \pm 2.34$ & $22.66 \pm 7.55$ \\
& After & $1.20 \pm 0.54$ & $56.52 \pm 33.83$ & $18.42 \pm 17.72$ & $82.85 \pm 9.73$ \\
& & $\mathrm{P} \leq 0.05$ & $\mathrm{P}=0.076$ & $\mathrm{P} \leq 0.012$ & $\mathrm{P} \leq 0.05$ \\
G. lucida & Before & $2.18 \pm 0.53$ & $75.16 \pm 9.81$ & $19.31 \pm 7.36$ & $14.17 \pm 6.76$ \\
& After & $0.92 \pm 0.14$ & $77.18 \pm 35.47$ & $15.31 \pm 6.42$ & $59.98 \pm 3.45$ \\
& & $\mathrm{P} \leq 0.05$ & $\mathrm{P}=0.719$ & $\mathrm{P}=0.138$ & $\mathrm{P} \leq 0.05$ \\
\hline
\end{tabular}

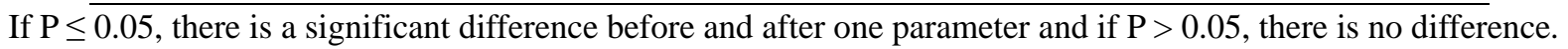

We found that during the early wound healing, all species produced vessels with smaller area than in unaffected wood and this significantly decreased the specific conductive area in the investigated species $(\mathrm{P} \leq 0.05)$.The opposite trend was observed for parenchyma areas which increase significantly in wound wood. The fiber areas of $A$. boonei and $S$. zenkeri have increased significantly in the regenerated wood while no difference was observed between G. lucida wood before and after debarking. Areas occupied by fibers where comparable in $S$. zenkeri and G. lucida wood except for A. boonei.

\section{Discussion}

Wounding of trees by debarking during the vegetative period sometimes results in the formation of callus tissues which develops over the entire wound surface or on parts of it (Stobbe et al., 2002). Shortly after callus formation, it differentiates to form wound wood which is anatomically different than normal wood. Six months after debarking, A. boonei, S. zenkeri and G. lucida wound closure began simultaneously from the margins of the wound and from the entire exposed surface of the wounded xylem, since in the bark, a ligno-suberized layer is formed primarily around the wound, thus rapidly protecting unaffected tissues against water loss and invasion by microorganisms (Oven et al., 1999). This was clearly visible for the three species, which showed no attack by microorganisms. At the end of the experiment, no individual died and this situation could be explained by the fact that the debarking does not concern the entire circumference of the tree, in which case the growth of the tree could be disturbed, because considerable wound could damages conduction tissue that is the phloem for the nutriments and the xylem for water.

Alstonia boonei is the species which has a higher bark recovery speed. The speed of recovery of the bark is raised more rapid the six first months after barking. Mwange et al. (2003) showed that the content of auxin decreases at advanced stages of the healing and, consequently, a reduction of the concentration of auxin involves a slower differentiation of the vessels, which could explain the weak rate of covering of the bark twelve months after barking. The results of this study confirm that wounding induces the formation of narrower vessels (Lowerts et al., 1986; Arbellay et al., 2010; Momo et al., 2017). More and narrower early wood vessels considerably reduced xylem relative conductivity and xylem vulnerability to cavitation in the injury wood, attesting to the functional need of trees to balance xylem hydraulic efficiency against xylem safety from embolism (Sperry et al., 2008). The reduction of vessel lumen size led to a greater thickness-to-span ratio of vessels, which translates into higher wood density except in $S$. zenkeri, greater mechanical reinforcement, and greater resistance to cavitation (Lens et al., 2011).Indeed, the low-size vessels contribute to a surer system of control and play a role of adaptive mechanism to protect tree (Verheyden et al., 2005). According to Delvaux et al. (2009), Vessels appeared to be very good anatomical indicators of the tree's reactions to debarking. Spatial changes in the wood features after bark harvesting damage were much less important than temporal changes. Recovery of the vessel features (size, density) towards their condition before wounding is a slow process that requires at least two years to complete even like $A$. boonei just take 15 months to heal its wound.

The closure of the wound begins with the formation of callus tissue consisting of soft tissue masses of the parenchyma (Fahn, 1985), that gradually invade the wound surface. Globally in this study, area occupied by parenchyma has increased considerably in the wound wood, and this is normal since cambial injury stimulates the production of parenchyma around the wound in order to protect the living tissue (Schmitt \& Leise, 1990). In fact, in times of environmental stresses, tree metabolism is subject to economic principles. Tree priorities following wounding include there-establishment of xylem mechanical strength and xylem safety from embolism, 
which were found to occur through an increase in the callus mass, but at the expense of water transport and hence future tree growth. The higher proportion of radial parenchyma in the callus tissue corresponds to a considerable effort for defence against pathogens (compartmentalization) and wound healing (Schweingruber, 2007).

\section{Conclusion}

To conclude, A. boonei, S. zenkeri and G. lucida react well to debarking since no individual died after experimentation. The study provides detailed information on the duration and anatomical changes that occurs in response to experimental damage. A boonei regenerates its bark more rapidly than S. zenkeri and G. lucida. Recovery of the vessel features (size, density) towards their condition before wounding requires at least fifteen months to be completed.

\section{Acknowledgement}

The authors are grateful to the International Foundation of Science (IFS) for providing grant for this project titled «Anatomical response to the peeling of some species of economic interest for the rational management of natural resources in Cameroon», grant number No. 1I1_D_5471 - RenApp_REV.

\section{References}

Arbellay, E., Stoffel, M., \& Bollschweiler, M. (2010). Wood anatomical analysis of Alnus incana and Betula pendula injured by a debris-flow event. Tree Physiology, 30, 1290-1298. https://doi.org/10.1093/treephys/tpq065

Awono, A., Atyi, R. E., Foundjen-Tita, D., \& Levang, D. (2016). Vegetal non-timber forest products in Cameroon, contribution to the national economy. International forestry review, 18(1), 1465-5489. https://doi.org/10.1505/146554816819683708

Bello, I. S., Oduola, T., Omisore, N. O. A., Raheem, G. B. O., \& Ademosun, A. A. (2009). Evaluation of Antimalarial Activity of Various Fractions of Morinda lucida Leaf Extract and Alstonia boonei Stem Bark Global Journal of Pharmacology, 3(3), 163-165. https://doi.org/RG.2.2.13010.91849

Bitariho, R., Mcneilage, A., Babaasa, D., \& Barigyira, R. (2006). Plant harvest impacts and sustainability in Bwindi Impenetrable National Park, S.W Uganda. African Journal of Ecology, 44, 14-21. https//doi.org/10.1111/J1365-2028.2006.00597x

Burkhill, I. H. (1985). The Useful Plants of West Tropical Africa. Vol. 1, Families A-D. Royal Botanic Gardens, Kew. pp. 687. https://doi.org/10.18167/74726F706978

Cunningham, A. B. (2001). Applied Ethnobotany: People Wild Plant Use and Conservation. Earthscan Publications Ltd., London WWF. Rome. https://doi.org/10.1663/0013-0001

Delang, C. O. (2006). Economic valuation of non-marketed wild edible plants in Thailand. Environmental Conservation, 32(4), 285-287. https://doi.org/10.1017/S037689290600258X

DeWasseige, C., Devers, D., de Merken, P., Eba'aAtyi, R., Nasi, R., \& Mayaux, P. (2009). Les forêts du Bassin du Congo: Etat des forêts 2008. Office des Publications de l'Union Européenne, Bruxelles, Belgique. https://doi.org/10.9789279132117

Delvaux, C., Sinsin, B., Darchambeau, F., \& Van Damme, P. (2009). Recovery from bark harvesting of 12 medicinal tree species in Benin, West Africa. Journal of Applied Ecology, 46, 703-712. https://doi.org/10.1111/j.1365-2664.2009.01639.x

Droissart, V., Dauby, G., Hardy, O. J., Deblauwe, V., Harris, D. J., Jans-sens, S., \& Couvreur, T. L. P. (2018). Beyond trees: Biogeographical regionalization of tropical Africa. Journal of Biogeography, 45, 1153-1167. https://doi.org/10.1111/jbi.13190

Droissart, V., Lachenaud, O., Dauby, G., Dessein, S., Kamdem, G., Nguembou, C., \& Sonké B. (2019). Mine versus Wild: a plant conservation checklist of the rich Iron-Ore Ngovayang Massif Area (South Cameroon). Plant Ecology and Evolution, 152(1), 8-29. https://doi.org/10.5091/plecevo.2019.1547

Esau, K. (1967). Plant anatomy. John Wiley \& Sons, New York, NY.

Evert, R. F. (2006). Esau's Plant anatomy: meristems, cells, and tissues of the plant body: their structure, function, and Development, Wiley J. and Sons, Inc. Hoboken, New Jersey, USA. https://doi.org/10.1002/0470047380

Eyog, O. M., Ndoye, O., Kengue, J., \& Awono, A. (2006). Les fruitiers forestiers comestibles du Cameroun. 
International Plant Genetic Resources Institute. pp. 178.

Fahn, A. (1985). Plant anatomy (3 ed.).Pergamon Press, Oxford.

FAO (Food and Agriculture Organization of the United Nation). (2018). La situation résumée des forets du monde. Les forêts au service du Développement durable. pp. 28.

FAO (Food and Agriculture Organization of the United Nation). (2020). Forêts, biodiversité et activité humainedes forets du monde Situation des forets du monde. pp. 31.

Geldenhuys, C. J., Syampungani, S., Meke, G. S., \&Vermeulen, W. J. (2007). Response of different species to bark harvesting for traditional medicine in Southern Africa. In Bester et al. (Eds.), Multiple Use Management of Natural Forests and Woodlands: Policy refinement and scientific progress (pp 55-62). Department of Water Affairs and Forestry, Pretoria, South Africa.

Guedje, M. N., Tadjouteu, F., Onana, J. M., Nnanga, N. E., \& Ndoye, O. (2017). Garcinia lucida Vesque (Clusiaceae): from traditional uses to pharmacopeic monograph for an emerging local plant-based drug development. Journal of Applied Biosciences, 109, 10594-10608. https://doi.org/10.4314/jab.v109i1.4

Hall, P., \& Bawa, K. (1993). Methods to assess the impact of extraction of non-timber tropical forest products on plant populations. Economic Botany, 47(3), 234-247. https://doi.org/10.1007/BF02862289

Kuepetou, R. M., Owona, A. M. L., Njingti, N., \& Manguelle-Dicoum, E. (2017). 3D Modelling from New and Existing Gravity Data of an Intrusive Body in the Northern Part of Kribi-Campo Sub-Basin in Cameroon. International Journal of Geosciences, 8, 984-1003. https://doi.org/10.4236/ijg.2017.88056

Lens, F., Sperry, J. S., Christman, M. A., Choat, B., Rabaey, D., \& Jansen, S. (2011). Testing hypotheses that link wood anatomy tocavitation resistance and hydraulic conductivity in the genus Acer. New Phytologist, 190, 709-723. https://doi.org/10.1111/j.1469-8137.2010.03518.x

Lowerts, G., Wheeler, E. A., \& Kellison, R. C. (1986). Characteristics of wound-associated wood of yellow poplar (Liriodendron tulipifera L.). Wood and Fiber Science, 18, 537-552. https://doi.org/10.56163455

Mahapatra, A., \& Mitchell, C. P. (1997). Sustainable development of non-timber forest products: Implication for forest management in India. Forest Ecology and Management, 94, 15-29. https://doi.org/10.1016/S0378-1127(97)00001-7

Mioumnde, A. P., Mbou, F. A. K., KuePetou, R. M., Kabir, S. A., Bessong, M., \& Liqiang, Z. (2019). Sediment logical Studies of Alluvium Deposits along Ngovayang-Bipindi of Lokoundje River, Southwestern Cameroon. International Journal of Geosciences, 10, 119-139. https://doi.org/10.4236/ijg.2019.101008

Mohr, H., \& Schopfer, P. (1995). Plant physiology. Springer-Verlag, Berlin, Heidelberg, New York. https://doi.org/10.1007/978-3-642-97570-7

Momo, Solefack, M. C., Beeckman, H., Temgoua, L. F., \& Kenguem, K. G. (2017). Anatomical characteristics of Garcinia lucida (Vesque) and Scorodophloeu szenkeri (Harms) wood and debarking response in the south region Cameroon. Sustainable Agriculture Research, 6(4), 132-141. https://doi.org/10.5539/sar.v6n4p132

Mwange, K. N., Hou, H. W., \& Cui, K. M. (2003). Relationship between endogenous indole-3-acetic acid and abscisic acid changes and bark recovery in Eucommia ulmoides Oliv. after girdling. Journal of Experimental Botany, 54, 1899-1907. https://doi.org/10.1093/jxb/erg204

Oven, P., Torelli, N., Shortle, W. C., \& Zupancie, M. (1999). The formation of lingo-suberized layer and necrophylactic periderm in beech bark (Fagus sylvatica L.). Flora, 194, 137-144. https://doi.org/10.1016/S0367-2530(17)30892-7

Palla, F. (2005). Alstonia boonei De Wild. Prota plant resource végétale d'Afrique tropicale Wageningen Netherland.

Reardon, T., Delgado, C., \& Matlon, P. (1992). Determinants and effects of income diversification amongst farm households in Burkina Faso. The Journal of Development Studies, 28(2), 264-296. https://doi.org/10.1080/00220389208422232

Reardon, T., Berdegue, J., \& Escobar, G. (2001). Rural nonfarm employment and incomes in Latin America: overview and policy implications. World Development, 29(3), 395-409. https://doi.org/10.1016/S0305-750X(00)00112-1

Ruben, R., \& Van den Berg, M. (2001). Nonfarm employment and poverty alleviation of rural farm households 
in Honduras. World Development, 29(3), 549-560. https://doi.org/10.1016/S0305-750X(00)00107-8

Schmitt, U., \& Liese, W. (1990). Wound reaction of the parenchyma in Betula. IAWA Bulletin, 11, 413-420. https://doi.org/10.1163/22941932-90000531

Schweingruber, F. H. (2007). Wood structure and environment. Berlin, Germany: Springer.

Sellin, A., Rohejarv, A., \& Rahi, M. (2008). Distribution of vessel size, vessel density and xylem conducting efficiency within a crown of silver birch (Betula pendula). Trees-Structure and Function, 22, 205-216. https://doi.org/10.1007/s00468-007-0177-4

Sheil, D., \& Liswanti, N. (2006). Scoring the importance of tropical forest landscapes with local people: Patterns and insights. Environmental Management, 38(1), 126-136. https://doi.org/10.1007/s00267-005-0092-7

Sperry, J. S., Meinzer, F. C., \& McCulloh, K. A. (2008). Safety and efficiency conflicts in hydraulic architecture: scaling from tissues to trees. Plant, Cell and Environment, 31, 632-645.

https://doi.org/10.1111/j.1365-3040.2007.01765.x

Stewart, K. M. (2003). The African cherry (Prunus africana): can lessons be learned from an over-exploited medicinal tree?. Journal of Ethnopharmacology, 89, 3-13. https://doi.org/10.1016/j. jep.2003.08.002

Stobbe, H., Schmitt, U., Eckstein, D., \& Dujesiefken, D. (2002). Developmental stages and fine structure of surface callus formed after debarking of living lime trees (Tilia sp.). Annals of Botany, 89(6), 773-782. https://doi.org/10.1093/aob/mcf137

Suchel, J. B. (1972). La répartition des pluies et les régimes pluviométriques au Cameroun. Travaux et Documents de Géographie Tropicale. Bordeaux, Yaoundé, CEGET -CNRS.

Ticktin, T. (2004). The ecological implications of harvesting non-timber forest products. Journal of Applied Ecology, 41, 11-21. https://doi.org/10.1111/j.1365-2664.2004.00859.x

Tsobou, R., Hamawa, Y., Fawa, G., Tatsimo, N. S. J., Avana, T. M. L., Wouokoue, T. J. B., \& Van Damme, P. (2020). Can antimalarial, antiviral and anti-respiratory infections Cameroonian medicinal plants be used as one of the potential ways to cure COVID-19? Pharmacological and ethnomedicinal proof. Journal of Medicinal Herbs and Ethnomedicine, 6, 61-85. https://doi.org/10.25081/jmhe.2020.v6.6240

Turner, W. R., Brandon, K., Brooks, T. M., Gascon, C., \& Gibbs, H. K. (2012). Global Biodiversity Conservation and the Alleviation of Poverty. Bioscience, 62, 85-92.

https://doi.org/10.1525/bio.2012.62.1.13

Verheyden, A., De Ridder, F., Schmitz, N., Beeckman, H., \& Koedam, N. (2005). High-resolution time series of vessel density in Kenyan mangrove trees reveal a link with climate. New Phytologist, 167(2), 425-35. https://doi.org/10.1111/j.1469-8137.2005.01415.x

Vermeulen, W. J. (2009). The sustainable harvesting of non-timber forest products from natural forests in the southern Cape, South Africa: development of harvest systems and management prescriptions (Unpublished $\mathrm{PhD}$. Dissertation). Stellenbosch University, Stellenbosch, South Africa.

Wardle, P., \& Kaoneka, A. R. S. (1999). Perceptions and Concepts of the Importance of Forests. In M. Palo, \& J. Uusivuori (Eds.), World Forests, Society and Environment. World Forests, vol 1. Springer, Dordrecht. https://doi.org/10.1007/978-94-010-0664-4_11

Waterloo, M. I., Ntonga, J. C., Dolman, A. J., \& Ayangma, A. B. (2000). Impact of shifting Cultivation and selective logging on the hydrology and erosion of rain forest land in South Cameroon. Tropenbos-Cameroon Documents 3.Tropenbos-Cameroon, Kribi.

Wunder, S. (2001). Poverty alleviation and tropical forests - What scope for synergies?. World Development, 29, 1817-1833. https://doi.org/10.1016/S0305-750X(01)000070-5

Zwieniecki, M. A., Melcher, P. J., Field, T. S. \& Holbrook, N. M. (2004). A potential role for xylem-phloem interactions in the hydraulic architecture of trees: effects of phloem girdling on xylem hydraulic conductance. Tree Physiology, 24, 911-917. https://doi.org/10.1093/treephys/24.8.911 


\section{Copyrights}

Copyright for this article is retained by the author(s), with first publication rights granted to the journal.

This is an open-access article distributed under the terms and conditions of the Creative Commons Attribution license (http://creativecommons.org/licenses/by/4.0/). 